\title{
The ageing demographic transition: The impact on elderly and social workers
}

\author{
Robyn Aldrich
}

Robyn Aldrich is presently employed at Waitemata District Health Board as a Social Work Case Manager in Early Psychosis Intervention. Robyn spent time last year working with elderly at Auckland District Health Board's Mental Health Services for Older People, while doing a postgraduate degree in allied mental health at Victoria University.

\section{Abstract}

The issues associated with an ageing population pose substantial challenges for governments globally. Social workers are well suited to respond to the challenges of this demographic change. However, there is a severe shortage of social workers that are skilled in working in this field. This article looks at the ageing demographic transition, how support for the increasing older population will be a problem, and the issues that may impact older people, as well as social workers. How discrimination, culture and ethics inform social work practice, and the legislation and policies that are available for the aged. The article also looks at the knowledge, skills, values, beliefs and models of practice that are used by social workers in working with the older generation.

\section{Demographics of ageing}

As we head into the 21st century the New Zealand ageing population is increasing. Statistics New Zealand (2006) state that by 2051 there will be over 1.14 million people aged 65 and over in New Zealand. According to Dunstan and Thomson (2006) population ageing is wrongly attributed to the post-World War II baby boom. However, the baby boom only temporarily reversed a steady ageing process, which has seen persistently lower fertility rates, low birth numbers, and low mortality rates in New Zealand. Dunstan and Thomson state the increase in the elderly population is more accurately described as a 'demographic transition'. This demographic transition stems from socio-economic and health factors that are resulting in a rise in the average age of the population. Duncan (2004) concurs and adds that medical science is improving; therefore people are healthier and are consequently living longer.

\section{Challenges that will impact on the older person}

As faced by previous generations this elderly population will have physical, psychological and mental disabilities, depression, loss and chronic medical conditions. Some elderly will need assistance where families are unable to provide support and care due to family fragmentation (Chenoweth \& McAuliffe, 2005). 
Social isolation may be experienced along with poor access to social services and a lack of community activities and support. There will be housing issues, financial dilemmas and difficult end-of-life decisions. Various types of elder abuse are also a possibility, such as financial, physical and psychological abuse. These challenges already create significant demands on community care agencies, hospitals, rest homes, retirement villages and government resources. According to the Government (Beehive.govt.nz, 2006), a further increase in the elderly population will put strain on future finances and resources for health treatment, care and social services. However, Wilson and Rodway (2006) believe that as older people become more active, healthy and live longer they may have fewer years of bad health, thereby reducing health costs. Bevan (2001) disputes this stating that as people live longer they will become sicker. Duncan (2004) notes too that with fewer young people and children there will be fewer services required in other areas, such as education to make up for any financial shortfall. Wilson and Rodway (2006) reason that this is not certain, as older adults may seek educational opportunities financed by government.

There are further challenges that may impact older people as society copes with an increasing elderly population. Duncan (2004) maintains that retirement pensions will remain relatively low which may not provide many with the standard of living that they may have previously enjoyed. The remaining tax-paying society may possibly be resentful and perceive elderly citizens as a 'burden' on the economy. Participation and belonging in society may diminish, along with feelings of being undervalued and isolated. Also health systems and social services may be limited in providing for elderly needs.

Equally this older generation may present society with opportunities. Duncan states (2004) that a large number of elderly will have a significant amount of political and consumer power. As well Opal Cox, Kelchner and Chapin (2001) believe this generation of individuals will be far more educated and independent than previous generations. They will be more active, multi-skilled and productive, and many will continue to work beyond retirement age thus contributing a great deal to society (Glasgow, 2005).

\section{Ageism}

A further challenge for society, and the increasing older population is ageism. Thompson (2001) depicts ageism as a process where society discriminates and stereotypes people by virtue of old age. Ageism also reinforces fear and denigration of the ageing process thereby establishing myths and assumptions regarding the ability of older people. Elderly are often perceived as senile, frail, disabled, likely to live in institutions, unable to learn new skills, socially withdrawn and dependent (Glasgow, 2005). Apocalyptic demography is an ideology that apportions blame to the 'oncoming hordes of elderly' (Bevan, 2001) for driving up health care costs and soaking up resources, while shifting care and responsibility to individuals and their families as opposed to the state. Boston and Davey (2006) note similar attitudes, referring to the 'selfish generation' where it is perceived that a certain generation of New Zealanders have benefited from social policies of the 1950s-1960s, such as free tertiary education.

Social workers must challenge, eliminate or change these ageist attitudes through advocacy and education, by acting as conscious raisers of elderly rights and potentials (KirstAshman and Hull, 2006). Thompson (2001) notes social workers must make sure elderly 
are heard, consulted and where oppression has manifested in low self-esteem, empower, enhance self-esteem and proffer respect. Berkman, Gardner, Zodikoff and Harootyan (2005) reiterate that social workers must remain sensitive to discrimination of age, race, ethnicity, gender and socio-economic status to effectively assist individual and families. Social workers in New Zealand follow the ANZASW Code of Ethics thereby demonstrating a commitment to minimising discrimination and oppression, while valuing integrity, dignity, client participation and self determination.

\section{Cultural aspects of ageing}

According to Berkman et al. (2005), cultural sensitivity and competence are also essential in meeting the needs of a vulnerable ageing population. Browne and Broderick (1994) note that issues for social workers in working with ethnic aged people will be language, literacy, economic and cultural values, a lack of knowledge of what services are available, and a lack of trust in government services.

According to Dunstan and Thomson (2006) by 2021 Maori 65 and over will number 56,000 compared to 20,000 in 2001. It is interesting that, in a report by Age Concern based on referrals to Elder Abuse and Neglect Prevention services, of the 890 surveyed reports of abuse 737 were Pakeha and only 68 were Maori (Age Concern New Zealand, 2005b). Selby (1994) suggests this is because Maori elders are respected and appreciated for their skills and care giving, and are treated with great love and respect by whanau. Glasgow (2005) concurs, also noting that older Maori have more responsibility as they are called upon for their knowledge and leadership as kaumatua, and to look after whanau, hapu and iwi well-being

The New Zealand Positive Ageing strategy has affirmed Maori values in its future policies. The Treaty principles are also recognised under the Bicultural Code of Practice (Aotearoa New Zealand Association of Social Workers, 2004) where key areas for social workers are to strengthen the capabilities of older Maori and their whanau, include whanau in decision making, provide services to Maori by Maori with marae-based services and programmes, and to address income related issues experienced by Maori. For example Maori have been significantly affected by high rates of chronic illness, unemployment, redundancy and lower wages that have made it difficult to support whanau and save for retirement (Glasgow, 2005). Access to Maori health providers within communities, and opportunities for access to tertiary education and employment for younger generations are addressed in the policy. The policy also recognises the opportunity for kaumatua to pass on skills and knowledge, and of kaumatua being positive role models for younger generations (Glasgow, 2005).

\section{Recognising the older person}

Although the Declaration of Human Rights protects the rights of people, there is nothing within the declaration that specifically pertains to elderly. With the demographic transition being a worldwide phenomenon the United Nations announced the International Year of Older People in 1999 (United Nations, 2000). This was in recognition of contributions of elderly to societies, to promote issues and awareness of elderly, and to set out principles in areas such as independence, participation, care, self-fulfilment and dignity of older people. At the same time the WHO promoted its 'global movement for active ageing' to emphasise health and independence beyond physical well-being to entail social justice and citizenship 
(WHO, 1999). The International Federation on Ageing (IFA) is a global organisation formed to promote positive change for elderly and to improve understanding of ageing policies, practices and their impact on elderly. The IFA also encourages positive links between governments and organisations that deal with ageing issues.

\section{Gerontological social workers}

Significant are the changes that ageing has on the quality of life, and of the overwhelming need for supportive services for the ageing population. Dwyer (2006) also notes that there will be an increase in the demand for welfare, age-related organisations, disability and health-orientated services, and agencies that support carers. Boston and Davey (2006) maintain there will be a huge demand for not only skilled health care professionals, but also skilled social workers.

In New Zealand social workers for the elderly are mainly found in hospitals and community organisations such as Age Concern (Weir, W., personal communication, Age Concern, June 7, 2007). In America social workers are also found in residential facilities and are now mandatory in nursing homes (Gibson, Kunz, \& Schmidt, 2005). A Department of Labour assessment shows a shortage of social workers for elderly. In New Zealand only 3,500 social workers for elderly worked in community and social services in 2004.

America is also experiencing a severe shortage of social workers for elderly (Rosen \& Zlotnik, 2001), with only 5,000 of the 155,000 National Association of Social Work members employed with the aged. Rosen and Zlotnik put this down to a number of reasons: lack of knowledge about ageing issues, lack of appropriate training and competency, negative stereotypes of elderly, a belief that the work lacks challenge, is undervalued, and the widespread variation in pay, roles, quality of jobs and often the isolation in gerontological social work due to limited numbers of social workers working with elderly. Boston and Davey (2006) explore possible solutions such as training recruitment, appropriate training, increase remuneration, changing the way services are provided and defining job definitions. The latter has been addressed in New Zealand by establishing registration for social work to establish professional standards of competent practice, as well as protecting clients and social workers (Social Workers Registration Board, 2007).

Schofield (2005) says to adjust and meet the needs of this elderly demographic transition social workers will need to be innovative, resourceful and creative, for example: in promoting older people's needs to be able to acquire resource funding, because when working with a socially devalued group resources are not easily obtained. Evidence-based practice and research will also be required to demonstrate effectiveness of social work practice with elderly. Rosen and Zlotnik (2001) note that social workers will also need to acquire basic practice competency in age-related issues and ensure knowledge is updated.

Another issue for social workers is that the small number of Non-Government Organisations (NGO) that work with elderly are underfunded and many cannot afford to employ social workers, so will tend to employ community support workers or settle for volunteers. If an NGO can afford to pay for a social worker the pay can be minimal. Then there is the cost of registration, which both NGO and social workers may find costly. Ultimately the NGO may suffer and consequently the elderly as well, due to too few staff, unqualified staff 
and frustrated unregistered social workers on low incomes having to provide extra training, and do overtime without pay. Social workers that work with older people in government organisations typically receive nearly double the income than that of an NGO social worker. This may contribute to the difficulty of recruiting social workers to work with elderly (Weir, W., personal communication, Aged Concern, June 7, 2007).

\section{Social policies for the older population}

The Positive Ageing Strategy (Ministry of Social Policy, NZ Govt, 2001) is a vision that involves development and delivery of ageing guidelines through government policies, local government, community sectors, businesses and non-government organisations to provide support as people age. The theory behind the policy is that people who age well contribute and participate in society, and will be valued and respected by families and communities.

A New Zealand Positive Ageing Strategy (Ministry of Social Policy, NZ Govt, 2001) objective is to ensure secure and adequate income. To this affect New Zealand provides elderly with superannuation and provisions for monitoring and reviewing incomes. The main concern for the state is in sustaining this tax-payer funded superannuation. Thus the Government has stepped in with 'KiwiSaver' (KiwiSaver, 2007), a voluntary, work-based savings initiative to help with long-term saving for retirement with compulsory employer contributions. Most OECD countries emphasise individual responsibility to ageing with a reciprocal relationship between the individual and the state. Germany and the Netherlands rely heavily on earnings-related social insurance (Boston \& Davey, 2006).

Further goals for positive ageing are to promote equitable, affordable, timely and accessible health services, transport and housing options for elderly (Boston \& Davey, 2006). The ability for older people to have choices about where to live is termed 'ageing in place' and incorporates awareness of safety, services and support. The government contribution to an ageing population in the 2006 budget was for $\$ 126$ million to be put aside for improving home-based support services, and age-related residential care over the next four years (Beehive.govt.nz, 2006). A CloseUp (TVNZ, 2007) news item reported an alternative lifestyle called 'Abbeyfield' where elderly peers can go flatting at a fraction of the price of rest homes without giving up independence, while still maintaining the support and company of others. The Positive Ageing Strategy (Ministry of Social Policy, NZ Govt, 2001) covers Treaty principles discussed previously, as well as positive images of older people to address ageism. Lastly the strategy addresses increasing opportunities for personal growth, adult education and drawing on the skills and experience of our ageing citizens.

Legislation introduced for elderly under the Protection of Personal and Property Rights Act 1988 (Age Concern, n.d.) is the Enduring Power of Attorney offering protection from elder abuse. This gives authority for someone to look after property or the personal welfare and care of an older person in case of accident, illness or incapacity.

Conversely Boston and Davey (2006) state that as the population ages governments may have to make policy changes that impose negatively on elderly, such as reducing superannuation, establishing means testing, reducing the number or quality of social services, or 
increasing age-eligibility for assistance. Considering this Wilson and Rodway (2006) note that a broad range of policies will need to be introduced early and gradually to lessen the effect of an ageing population, while also providing a balance between economic, political and social considerations. Thus social workers need to actively support policies and programmes for older people to receive assistance, retain independence and maintain social participation (Bertera and Bailey-Etta, 2001). New changes to this legislation makes this more difficult and expensive.

\section{Eclectic knowledge base and interventions}

Social workers will also need to have an eclectic knowledge base to be effective in helping elderly (Kirst-Ashman and Hull, 2006). Berkman et al. (2005) note that social work with older people requires knowledge of mental health, medical, developmental and psychosocial issues, and the impact of the above on individuals and families. Other useful areas of knowledge are the process of health care and welfare systems, financial and legal structures, and public and private supports. An ability to adapt to new information, technology and scientific advances in treatment of diseases would also be beneficial to social workers.

Berkman et al. (2005), says bio-psychosocial assessment counselling, family practice and advocacy remain essential skills in working with elderly, along with organising community support, strengthening networks to enhance 'natural helpers', such as ministers and volunteers, and assisting other professionals to form groups or meetings. Specific to these tasks is communication skills and engagement to build trust, respect and rapport, so an older person feels safe to discuss personal issues (Kirst-Ashman \& Hull, 2006). Other skills include planning, decision making, problem solving and teaching skills. Berkman et al. (2005) also note that social workers will be required to modify and adapt practice skills and interventions at a faster rate as evidence-based knowledge is disseminated more rapidly.

Intervention with elderly according to Silverstone (2005) needs to go back to the traditional ecological social work perspective of the person-in-situation as opposed to the present management philosophies and 'in models of service delivery ... that are looking at the situation-in-person' (Silverstone, 2005). These philosophies seek to cut costs and are more concerned with the requirements of the agency. The concept of person-in-situation focuses more on the older person and their interactions with their environment at all levels (KirstAshsman and Hull, 2006).

Kirst-Ashman and Hull (2006) note that empowerment and strength-based models of practice are also used with elderly. Gibson et al. (2005) concur stating that there is emphasis on self-determination, strengths, resilience and on combating learned helplessness. Bertera and Bailey-Etta (2001) also note the integration of spirituality and religion in social work practice that support a holistic approach.

Obstacles in intervention with older people include feelings of being intimidated by professionals, or of being taken over (Bertera and Bailey-Etta, 2001). The Families Commission (2005) states that intervention can be complicated if an elderly client has limited cognitive functioning to make decisions, or if a client is too embarrassed to discuss family problems. 


\section{Ethics}

From an ethical standpoint Gibson et al. (2005) note care must be taken that an intervention does not leave a client vulnerable, and that the type of intervention is what the client wants. The social worker must be aware of the client's goals and objectives, and must also be careful neither to make assumptions about needs based on stereotypes nor to categorise problems (Thompson, 2001). Under ethical guidelines (ANZASW, 2004) a clinical social worker has an obligation to assess an elderly person's ability to make independent decisions, and the ability to be self-determining. There is also an obligation to enhance autonomy, to empower and the duty to protect the older person's safety and health, however these duties can conflict. For example according to Linzer (2004) there could be ethical considerations that can create a dilemma for the social worker should an elderly victim inform a social worker of abuse, but refuse assistance.

Linzer (2004) also notes that what a social worker may believe is advocacy may be seen as disloyalty by the organisation employing the social worker. However, Gibson et al. (2005) also stipulate that it is not disloyalty to let an organisation know it is failing its clients. Institutional abuse can be the result of ageist policies or practices of an organisation that may take away a person's dignity and independence, and occurs often where other people are making decisions for an older person (Age Concern, 2005). Other areas of ethics involve confidentiality. According to Chenoweth and McAuliffe (2005) most ethical dilemmas are to do with confidentiality. When working with elderly clients it is important to be open with regards to ethical issues. Many elderly would not understand confidentiality limitations; this would need to be clarified by the social worker.

Social workers also need to be aware of their own values and beliefs as it may affect practice (Golden \& Sonneborn, 1998). For example, if a social worker values independence then the social worker is more likely to do things 'with' rather than 'for' an elderly client. Population ageing has profound implications for families especially the 'sandwich generation' (Petrie, 2006). These are middle-age baby boomers who simultaneously care for children as well as parents, and who are often in paid employment, experience stress, role overload and financial hardship. The social worker needs to be aware of any assumptions that families should provide necessary support to elderly parents or that community organisations and policies will provide support to caregivers. Families are not always in a position to assist elderly due to lack of resources, availability, relationship problems or history. There also needs to be recognition that communities are limited as a source of care. Thus community development would inform an important part of social work practice, such as maintaining social networks for caregivers and elderly.

At times there may be conflicting values where the social worker may lose objectivity and effectiveness to work with a client (Golden \& Sonneborn, 1998). For example much of gerontological social work involves grief, loss and death. Thus work with an older person necessitates reflexive self-knowledge, maturity and a level of professionalism.

Lastly, an important value is recognising an older person for their uniqueness; personality, life experiences, religious and spiritual orientation and resources (Bertera \& Baily-Eta, 2001). This uniqueness can impact practice in a practical and positive way to provide comfort and solutions to issues and problems. 


\section{Social trends}

Advancement in health care and social work practice is expected to continue in the 21st century with the diversification and expansion of an elderly population.

Social trends in caring for older people sees more emphasis on informal family care that conflicts with policies that encourage women to work, thus putting stress on family care for elderly (Petrie, 2006). Also policies encouraging private retirement savings that conflict with policies encouraging young adults to rely on families financially for a period, and policies requiring families to assist their elderly to 'age in place'.

Berkman et al. (2005) note further trends show social workers called on as family therapists, mediators, consultants and advocates in addressing complex ethical medical decisions such as end of life care. Social workers will be key members of multi-disciplinary teams offering not only clinical, social, case management and advocacy services, but a comprehensive approach in physical, mental and social aspects of practice (Rosen \& Zlotnik, 2001).

Research on social work practice will be required to test existing methods of assessment, to develop new practices and to evaluate out-comes. Professional social work education programmes will need to integrate evidence-based research into the curriculum and teach empirically derived intervention practice approaches specifically for elderly in social work practice.

A significant trend with the increasing number of elderly over the age of 85 , termed 'old-old', leaves questions as to whether these elderly will be 'able old' or 'frail old' (Bertera and Bailey-Etta, 2001), and whether more health-related services will be required, which according to Wilson and Rodway (2006) is difficult to predict.

In conclusion, an ageing population offers opportunities for all concerned, nationally and globally to campaign for a society where older people are recognised, respected and valued as active and contributing members of society. Social workers in particular are in a unique position to be consciousness raisers to this effect. Ageing is part of life and in an era of dramatic demographic change gerontological social workers can rise to the challenge by working in a variety of ways to enhance the well-being of older persons and their families.

\section{References}

Age Concern New Zealand. (2005a). Age concern New Zealand releases report on elder abuse E neglect prevention service: Media statement. Retrieved May 17, 2006 from www.ageconcern.org.nz/ ? / article\&id=000000107

Age Concern New Zealand. (2005b). Age concern elder abuse and neglect prevention services: An analysis of referrals for period: 1 July 2002 to 30 June 2004. Wellington: Author.

Age Concern, (n.d.). Do you have an enduring power of attorney?: Planning for your future. [Brochure]. Wellington: Author.

Aotearoa New Zealand Association of Social Workers Incorporated. (2004). Code of ethics. Dunedin: Author.

Beehive.govt.nz. (2006). Budget 06: Caring for older New Zealanders. Retrieved May 29, 2007 from http:/ / www. beehive.govt.nz / ViewDocument.aspx?DocumentID=25803

Berkman, B., Gardner, D., Zodikoff, B., \& Harootyan, L. (2005). Social work in health care with older adults: future challenges. Families in Society, 86(3), 329-338. Retrieved May 17, 2007 from ProQuest Social Science Journals database.

Bertera, E., \& Bailey-Etta, B. (2001). Physical dysfunction and social participation among racial/ethnic groups of older Americans: implications for social work. In F. Ahearn. (Ed.). Issues in global aging (pp. 97-115). London: Haworth Press Inc. 
Bevan, C. (2001). An ageing society issues and challenges. Australasian Journal on Ageing, 20, \#15-21.

Boston, J., \& Davey, J. (2006). Politics of ageing. In J. Boston \& J. Davey (Eds.), Implications for population ageing: Opportunities and risks (pp. 363-372). Wellington: Institute of Policy Studies.

Browne, C., \& Broderick, A. (1994). Asian and Pacific Island elders: Issues for social work practice and education. Social Work, 39(3), 252-259. Retrieved May 17th, 2007 from ProQuest Social Science Journals database.

Chenoweth, L., \& McAuliffe, D. (2005). The road to social work E human service practice: An introductory text. Victoria: Thomson Nelson Australia.

Department of Labour. (n.d.). Social worker: occupational skill shortage assessment. Retrieved May 25, 2007 from http: / / 72.14.253.104/ search?q=cache:Xe66dinYEA0J:www.workinsight.govt.nz / PDFs / professional-reportsocial-worker.pdf+social+work+and+elderly\&hl=en\&ct=clnk\&cd=4\&gl=nz

Duncan, G. (2004). Society and politics: New Zealand social policy. Auckland: Pearson Education New Zealand.

Dunstan, K., \& Thomson, N. (2006). Demographic trends. In J. Boston \& J. Davey (Eds.), Implications for population ageing: Opportunities and risks (pp. 11-49). Wellington: Institute of Policy Studies.

Dwyer, M. (2006). Communities and volunteering. In J. Boston \& J. Davey (Eds.), Implications for population ageing: Opportunities and risks (pp. 11-49). Wellington: Institute of Policy Studies.

Families Commission. (2005). Beyond zero tolerance: Key issues and future directions for family violence work in New Zealand. Retrieved May 17, 2006 from http:/ / www.familiescommission.govt.nz/download/zero-tolerance.pdf

Gibson, F., Kunz, J., \& Schmidt, M. (2005). A social work perspective. In B. Haight \& F. Gibson, Working with older adults (4th ed.) (pp.397-415). London: Jones and Bartlett Publishers.

Glasgow, K. (2005). Ageing is living: A guide to positive ageing. Wellington: Age Concern New Zealand Incorporated.

Golden, R., \& Sonneborn, S. (1998). Ethics in clinical practice with older adults: recognising biases and respecting boundaries. Generations, 22(3), 82-87. Retrieved May 17, 2007 from ProQuest Social Science Journals database.

Green. P. (1994). Studies in New Zealand social problems (2nd ed.). Palmerston North: The Dunmore Press.

International Federation on Ageing, (n.d.). Welcome to international federation on ageing. Retrieved July 4, 2007 from http:/ / www.ifa-fiv.org/en/accueil.aspx

Kirst-Ashman, K., \& Hull, Jr. G. (2006). Understanding generalist practice (4th ed.). California: Thomson Learning.

KiwiSaver (2007). Retirement saving made easy with KiwiSaver. Retrieved June 30, 2007 from http: / / www.kiwisaver. govt.nz/

Linzer, N. (2004). An ethical dilemma in elder abuse. Journal of Gerontological Social Work, 43(2/3), 165-173. Abstract retrieved May 17, 2006, from ProQuest Social Science Journals database.

Ministry of Social Policy. (2001). The New Zealand positive ageing strategy: Towards a society for all ages - He anga orange kau mo nga whakatipuranga katoa. Wellington: Author.

Opal Cox, E., Kelchner, E., \& Chapin, R. (2001). (Eds.). Gerontological social work: Issues challenges and potential. New York: Haworth Press.

Petrie, M. (2006). Implications of population ageing for families. In J. Boston \& J. Davey (Eds.). Implications for population ageing: Opportunities and risks (pp. 307-328). Wellington: Institute of Policy Studies.

Rosen, A., \& Zlotnik, J. (2001). Social work's response to the growing older population. Generations, $25(1), 69-72$. Retrieved May 17, 2007 from ProQuest Social Science Journals database.

Schofield, V. (2005). Health social work. In M. Connolly (Ed.), New Zealand social work: Contexts and practice (pp. 146-156). Victoria: Oxford University Press.

Selby, R. (1994). My whanau. In R. Munford, \& M. Nash (Eds.). Social work in action (pp. 144-151). Palmerston North: Dunmore Press.

Silverstone, B. (2005). Social work with the older people of tomorrow: Restoring the person-in-situation. Families in Society, 86(3), 309-320. Retrieved May 17, 2007 from ProQuest Social Science Journals database.

Social Workers Registration Board. (2007). Welcome. Retrieved July 4, 2007, from http: / www.swrb.org.nz/

Statistics New Zealand. (2006). Population ageing in New Zealand. Retrieved May 18, 2006 from http:// www.stats. govt.nz/products-and-services / Articles / pop-ageing-Feb00.htm

Thompson, N. (2001). Anti-discriminatory practice (3rd ed.). New York: Palgrave.

TVNZ, (2007). CloseUp: Flatting for oldies. Retrieved June 27, 2007 from http:/ / tvnz.co.nz/view / video_popup_windows_skin/1204755

United Nations. (2000). United Nations principles of older persons. Retrieved July 4, 2007 from http: / / www.un.org/ esa/socdev/iyop/iyoppop.htm

Wilson, P. \& Rodway, P. (2006). Ageing and the long term fiscal position. In J. Boston \& J. Davey (Eds.), Implications for population ageing: Opportunities and risks (pp. 99-125). Wellington: Institute of Policy Studies.

World Health Organisation. (1999). Global movement for active ageing. Retrieved July 4, 2007, from http:/ / www. who.int/hpr/globalmovement/index/htm 